\title{
Figures, Diagrams and Tables
}

\section{FIGURES}

1.1 Aggregate of all national current accounts according to IMF 1

$2.1 \quad$ Shares of final expenditure in GPP $(1970-2010)$

2.2 Share of the shadow economy in per cent of GPP (1960s 2000s)

3.1a GPP $1980-2011$ in trillions US\$, current prices 26

3.1b Growth rate of GPP $1980-2011$

3.2a GPP 1996-2002, in trillions US\$, current prices 29

3.2b Annual growth rate of GPP $(1996-2002) \quad 29$

3.3 Earth inflation rates in per cent $(1980-2011) \quad 30$

3.4 Earth Price Index Numbers $(2000=100) 1980-2011$

$3.5 \quad$ Real and nominal annual GPP growth $(1980-2011)$

3.6 Real GPP growth and planet inflation (per cent, 1980 2011)

$3.7 \quad$ Earth unemployment rate in per cent $(1991-2011)$

3.8 Earth unemployment and inflation $(1997-2011) \quad 36$

4.1 The condition $\mathrm{I}=\mathrm{S}$ in the Earth economy (Gross planet saving and investment in per cent of GPP, 1980 - 2011) 40

5.1 Earth's investment (in 1980 prices) versus long-term US interest rate in per cent, $1980-2011$

5.2 Decreases in gross planet investment (trillions of US\$) lead recessionary periods (shaded areas) $\quad 59$

6.1 Policy mix in 2009 (percentage of countries with stimulating monetary and fiscal policies) 62

6.2 Government expenditure and revenue shares in GPP (per cent, 2000 - 2011)

6.3 Earth's poverty pockets (2004) 67

6.4 Lorenz curve (approximate planet income distribution by quintiles $(1990$ - 2007)

6.5 Global Gini-coefficients $(1820-2002)$ in per cent according to Milanovich (2006) 69

6.6 Globally super rich (per cent of GPP, $1910-1990)$ 
6.7 Earth's fiscal balance and public debt $(2001-2011$, per cent of GPP)

7.1 Growth rate of Eurocurrency in circulation 75

7.2 Global velocity (GPP/M2) $1980-2010$

7.3 Global (production weighted) monetary policy rate (2000 April 2012)

7.4 Quantitative easing (Major central bank balance sheets in per cent of GPP, end of period 2007 - 2012Q1)

8.1a Earth output gap (1991 - March 2012, in per cent)

8.1b World industrial production and potential world industrial production (index numbers, 1991 - March 2012)

8.2 Okun's Law: Earth output gap and unemployment rate in per cent, $2001-2011$ )

9.1 Earth money growth and inflation 1984 - 2010 109

10.1 Two millennia of population and production

10.2 Two millennia of the drivers of real GPP growth (end of period, annual averages)

10.3 Drivers of real GPP growth (1951 - 2008, end of period, annual averages)

10.4 Population pyramids 1950 - 2050 (per cent of age cohort) 117

10.5 Earth capital stock 2005 (trillions of US\$)

10.6 World labour productivity and capital per worker in 1965 and 1992 (at international 1985 prices and dollars)

11.1 World fertility (children per woman) $1950-2050$

11.2 World mobile cellular subscriptions (millions, 1980 - 2010)

11.3 Countries with a competition law in 1980 (left) and 2005 (right)

12.1 Average growth rates of real GPP in per cent during identified phases in Kondratieff cycles 1820 - 2011

13.1 KOF index of globalization, $1970-2009$

13.2 Costs in terms of duration of increased participation in multilateral trade negotiations (GATT and WTO, $1946-$ present)

13.3 Atmospheric carbon dioxide concentration $1000-2010$ in ppm

13.4 Concentration in the world economy $1500-2008$

14.1 Population and production shares of key players at the start of the waves of global integration (1950s - 2000s)

14.2 GPP shares of China, EU27 and the United States and Herfindahl index of the Earth economy 2010 - 2050

$14.3 \quad$ Number of democracies worldwide, 1989 - 2011 


\section{DIAGRAMS}

2.1 Simple circular flow model of Earth economy 12

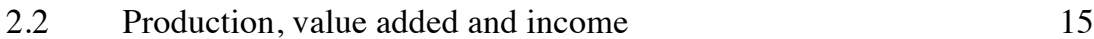

$\begin{array}{ll}2.3 & \text { Planet Accounting Matrix }\end{array}$

3.1 Key concepts in business cycle analysis 28

4.1 A simple consumption function 41

4.2 Life cycle consumption pattern 42

4.3 I $=$ S equilibrium in the Earth economy 44

4.4 Different concepts of stability 45

4.5 Linear (left) and non-linear (right) curve 48

4.6 Graphical representation of multiplier process 49

5.1 NPV of a an investment of 35 at $t=0$ with four positive payoffs of 10 in the periods $t=1,2,3,4$ for different interest rates

$\begin{array}{lll}5.2 & \text { The IS curve } & 55\end{array}$

$5.3 \quad$ Graphical derivation of the IS curve 56

6.1 Proportional and progressive tax schedules 64

7.1 Components of money demand 77

7.2 An increase in the supply of money reduces the interest rate 78

$\begin{array}{lll}7.3 & \text { The LM curve } & 79\end{array}$

$\begin{array}{lll}7.4 & \text { Graphical derivation of the LM curve } & 80\end{array}$

8.1 Construction of the eartheconomic demand and supply
model

8.2 Product market equilibrium and money market equilibrium in the ISLM model $\quad 86$

8.3 An increase in government spending in the ISLM model 87

8.4 Eartheconomic demand schedule 89

8.5 Demand contraction followed by expansionary fiscal and

$\begin{array}{lll}\text { 8.6 Tax cut at full employment } & 91\end{array}$

8.7 Isoquants without (left) and with (right) substitution 93

$\begin{array}{ll}\text { 8.8 Production functions with fixed technical coefficients (left) } & \\ \text { and substitution (right) }\end{array}$

8.9 Labour market (neoclassical) 94

8.10 Labour market with minimum wage 95

8.11 Long-run and short-run production functions 98

8.12 Eartheconomic demand and long-run/short-run supply 99

$\begin{array}{ll}\text { 9.1 Monetary policy is ineffective and fiscal policy is effective } & \\ \text { if the IS curve is interest insensitive } & 102\end{array}$

9.2 Relative interest rate (in)sensitivity of the IS curve 103

9.3 Liquidity trap and interest insensitive segment of LM curve 104 
9.4 A closer look at the liquidity trap

105

9.5 Austerity measures have a stronger impact in the liquidity trap

9.6 ISLM and full employment level

9.7 Neoclassical (left) and Keynesian (right) eartheconomic supply curves

9.8 Identification problems

$\begin{array}{ll}10.1 & \text { Solow production function in per capita terms } \\ 10.20\end{array}$

$\begin{array}{ll}10.2 & \text { The neoclassical growth model } \\ 10.3 & 123\end{array}$

$\begin{array}{lll}10.3 & \text { Increase in savings rate } & 124\end{array}$

10.4 Impact of an increase in saving on productivity (growth) and production growth

10.5 Transitory growth trajectories 126

11.1 Poverty trap in the Solow model 130

11.2 Increase in saving rate provides an escape from the poverty trap

11.3 Lower population growth can get the economy out of the poverty trap

11.4 Innovation and efficiency enhancement shift the production function up and lift the economy out of the poverty trap

11.5 Impact of structural reform on the product and the labour market

12.1 Summer, autumn, winter and spring characteristics of the Kondratieff wave

14.1 Multi-polar (left), multi-system (middle) and multi-lateral (right) governance

\section{TABLES}

2.1 Final spending components, 2009, trillions $\left(10^{12}\right)$ of US\$, current prices

2.2 Planetary accounts by economic activity, 2009, trillions of dollars, current prices

2.3 Planet income account for manufacturing sector at constant prices (1995 dollars)

6.1 Least Developed Countries that (can) achieve MDGs 70

12.1 Economic waves 